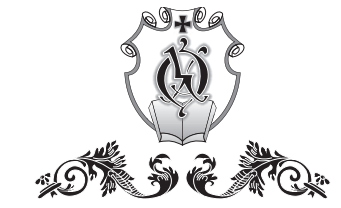

НАЦІОНАЛЬНИЙ УНІВЕРСИТЕТ

"ОСТРОЗЬКА АКАДЕМІЯ"

\title{
ГУМАНІТАРНЕ ПОЛЕ ГЕНДЕРНИХ ДОСЛІДЖЕНЬ
}

\author{
Колективна монографія
}

За редакцією Марії Петрушкевич

Острог

Видавництво Національного університету «Острозька академія» 2021 
УДК 396:001.89

ББК 71

Г 93

Друкується за рішенням ради гуманітарного факультету

Національного університету «Острозька академія»

(протокол № 5 від 23 грудня 2020 року)

\section{Рецензенти:}

Шевчук Катерина Сергіївна, докторка філософських наук, професорка, професорка кафедри філософії Рівненського державного гуманітарного університету;

Скорик Марфа Михайлівна, кандидатка філософських наук, директорка БО БТ «Київський інститут гендерних досліджень».

Гуманітарне поле гендерних досліджень: колективна монографія / за ред. Марії Петрушкевич. Острог. Видавництво Національного університету «Острозька академія», 2021. 120 с.

DOI 10.25264/23.12.2020

У колективній монографії представлене широке коло проблем з різних галузей науки: культурології, історії, дослідження масових комунікацій, соціології, релігієзнавства, філософії, всі вони об'єднані антропологічною проблематикою. Особливістю даного видання $€$ його різноспрямованість, вербалізація актуальних проблем усної історії, онлайн-активізму, узбаністичних студій. Одне із завдань монографії - зробити видимими, підтримати дослідження молодих науковиць. Авторки доводять, що антропологічна проблематика безпосередньо пов'язана із гендерними та феміністичними питаннями. Матеріали видання можуть стати у нагоді усім, кому не байдужий розвиток культури та суспільства, феміністичної та гендерної теорії.

удК 396:001.89

ББК 71

(C) Видавництво Національного університету «Острозька академія», 2021

(C) Автори, 2021 


\section{MICT}

\section{Тетяна Цимбал}

ГЕРОЇЗМ ТА ПОВСЯКДЕННІСТЬ В УСНИХ ІСТОРІЯХ УЧАСНИКІВ РЕВОЛЮЦІЇ ГІДНОСТІ (ГЕНДЕРНИЙ АСПЕКТ)

Алеся Соловей

ПРОГРАММЫ ПОДДЕРЖКИ ДЛЯ ЖЕНЩИН-УЧЕНЫХ

КАК МЕХАНИЗМ РАЗВИТИЯ ГЕНДЕРНОЙ ПОЛИТИКИ

В НАУЧНОЙ СФЕРЕ

\section{Марія Петрушкевич}

ФЕМІНІСТИЧНІ ЕЛЕКТРОННІ МАС-МЕДІА

В УКРАЇНСЬКОМУ СЕГМЕНТІ ІНТЕРНЕТУ: ТЕМАТИЧНА

РІЗНОМАНІТНІСТЬ РЕЛІГІЙНОЇ ПРОБЛЕМАТИКИ

Юлія Боровська, Вікторія Назарук

«ГЕНДЕРНІ ОКУЛЯРИ»: ПРИКЛАДИ СУЧАСНОГО

НЕДИСКРИМІНАЦІЙНОГО ПРОСВІТНИЦТВА

Вікторія Видиборець

ФЕМІНІСТИЧНИЙ ОНЛАЙН-АКТИВІЗМ

ЯК ВИД НИЗОВИХ ІНІЦІАТИВ

Яна Радченко, Павло Мірошниченко

ОБРАЗ ЖІНКИ В МАСОВІЙ СВІДОМОСТІ

ТА ЗАСОБАХ МАСОВОЇ ІНФОРМАЦІЇ

\section{Аліна Вознюк}

ДОКТРИНАЛЬНИЙ ВИМІР СЕКСУАЛЬНОСТІ, ЕРОТИЗМУ

ТА ЛЮБОВІ

Марія Панасюк

РЕЦЕНЗІЯ НА ЗБІРКУ «УРБАНІЗМ І ФЕМІНІЗМ»

ВІДОМОСТІ ПРО АВТОРІВ 
Наукове видання

\section{ГУМАНІТАРНЕ ПОЛЕ ГЕНДЕРНИХ ДОСЛІДЖЕНЬ}

\section{Колективна монографія}

За редакцією Марії Петрушкевич

\section{Комп'ютерна верстка Наталї̈ Крушинської Художнє оформлення обкладинки Романа Свинарчука}

На обкладинці використано репродукцію Пабло Пікассо "Дві дівчини, що читають" (1934)

Формат 42х30/4. Ум. друк. арк. 6,98. Обл.-вид. арк. 6,16.

Наклад 100 пр. Зам. № 79-20.

Папір офсетний. Друк цифровий. Гарнітура «Cambria».

Оригінал-макет виготовлено у видавництві Національного університету «Острозька академія», Україна, 35800, Рівненська обл., м. Острог, вул. Семінарська, 2. Свідоцтво суб'єкта видавничої справи РВ № 1 від 8 серпня 2000 року.

Виготовлено ФОП Свинарчук М. В. Тел. (+38068) 6835 800, e-mail: 35800@ukr.net. 